\title{
Community concerns and input for open pit closure in a West African urban setting
}

\author{
P.A. Varris Environment and Sustainability, Golden Star Resources Ltd., Ghana \\ M.B. Thorpe Sustainability, Golden Star Resources Ltd., USA
}

\begin{abstract}
The Plant North deposit abuts the Prestea community on Golden Star's Prestea Mining Concession, some $18 \mathrm{~km}$ south of Bogoso in the Western Region of Ghana. Operated by Golden Star (Bogoso/Prestea) Limited (GSBPL), mining of the Plant North deposit was approved for operation by the Environmental Protection Agency (EPA) in 2002. Although Prestea has been a mining town since the 1890s, previous mining was primarily underground. The Plant North pit development was the first open pit operation so close to the town of Prestea.
\end{abstract}

The Plant North operation was a key source of gold ore for the GSBPL Bogoso processing plant, however given its proximity to the urban population of Prestea, located within $1 \mathrm{~km}$, the operation was carried out with extensive limitations. Subject to close regulatory enforcement, a temporary stop work order and heavily constrained blasting provisions, the operation was completed in late 2006. At closure, the resulting landscape included an ore stockpile area, a partially backfilled open pit, waste dumps and a large section of pit void developed late in the project life. The project had also resulted in the covering of the Railway spring by waste dumping. Of symbolic and socio-economic importance to the community of Prestea, the Railway spring was a natural groundwater spring used for drinking and domestic purposes.

The Plant North Pit closure and rehabilitation plan was the first plan completed by GSBPL in consultation with local community for post closure land use. Based on the understanding that the pit would be backfilled, communities were given an opportunity to provide a next land use plan specifically addressing their needs. These had evolved through the operations and no longer reflected the provisional closure and rehabilitation plans that were included in the environmental impact assessment.

The closure and rehabilitation for the Plant North pit was delayed while GSBPL assessed its suitability for development of a portal to the adjacent underground resources. This delay resulted in the EPA establishing a permitting moratorium on GSBPL operations. The development of the portal proved not feasible and, with work being carried out on the pit backfilling, the EPA removed the permitting moratorium.

With the support from the community, the closure plan was subsequently approved by the EPA and backfilling was started in earnest in 2010. Backfilling of the pit was completed in late 2011, with about $12 \mathrm{Mm}^{3}$ of waste material being placed in the pit. During the work, the Railway spring was uncovered and rehabilitated, and the waste dump area was cleared back to original ground. Ongoing work with the community is now being carried out to rehabilitate the capped area of the pit.

Further community consultation in regards to closure land use is now being carried out to ensure that the stakeholders are aligned on the multi-use plan for the area. This plan includes a bus transport parking and loading area, agroforestry and areas of secondary tropical forest. It is anticipated that the rehabilitation work will contribute to the ongoing development of the town by providing economic stimuli to employment during the rehabilitation process and more significantly, later, through ongoing use of the area by the community members post closure.

GSBPL has learnt many lessons in regards to planning and implementation of closure, particularly in regards to communication and management of stakeholder needs and expectations, in the context of a dynamic mining industry. 


\section{Introduction}

Golden Star Resources Ltd (GSR) operates two gold mines and three processing plants in Ghana, West Africa. Golden Star (Bogoso/Prestea) Limited (GSBPL) operates a series of open pits and two processing plants near the towns of Bogoso and Prestea, with a current life of mine of some 12 years. Golden Star (Wassa) Ltd (GSWL) operates a series of open pits and a processing plant in the Mpohor and Akyempim area. All the operations are in the Western Region of Ghana (Figures 1 and 2) and are between $230 \mathrm{~km}$ and $270 \mathrm{~km}$ west of the capital Accra. GSR owns $90 \%$ of the two companies and the government of Ghana owns a $10 \%$ free-carried interest. Under a similar arrangement, GSBPL also owns $90 \%$ of the Prestea underground mine, which is presently under care and maintenance whilst project evaluations are completed following a positive preliminary economic assessment.

The Plant North area is on the Prestea Mining Concession, and is some $18 \mathrm{~km}$ south of the town of Bogoso and to the immediate northeast of the town of Prestea, in the Prestea-Huni Valley District, Western Region, Ghana. In the 2000 census, the local communities present in vicinity to the project area were home to some 32,000 people; by 2010 , this had risen to some 58,000 people.

GSR purchased the Bogoso Concession in 1999 and has operated the Bogoso non-refractory plant, processing gold-bearing ores when non-refractory feed was available. In 2001, GSR acquired the Prestea Concession, located adjacent to and south of the Bogoso Concession, and began mining the Prestea open pit deposits in late 2001. In late 2002, GSR acquired the GSWL operation, and constructed the Wassa processing plant, which began commercial operation in April 2005. In July 2007, GSR completed the construction and development of the Bogoso refractory (sulphide) plant to process the refractory ores using $\mathrm{BIOX}^{\circledR}$ technology.

In late 2005, GSR acquired the Hwini-Butre and Benso (HBB) properties. Benso mine development activities started in late 2007, and in 2008 GSWL began moving ore from the Benso mine to the GSWL plant for processing. Hwini-Butre mine development started in Quarter 4 2008, and in May 2009, the Hwini-Butre mine began transporting ore to the Wassa plant for processing. The mining operations in Ghana continue to be the primary revenue-generating stream for GSR.

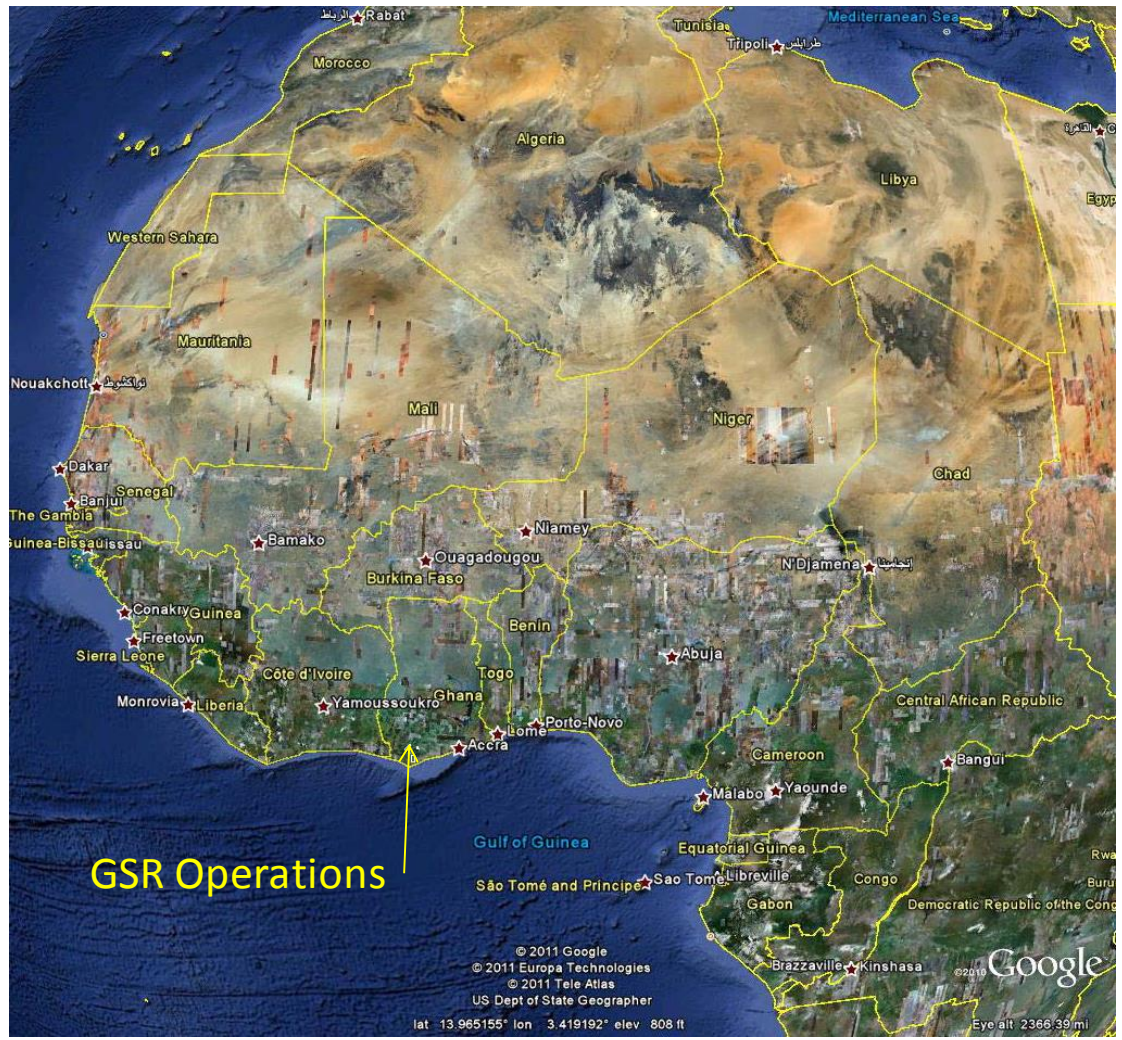

Figure 1 Regional GSR location 


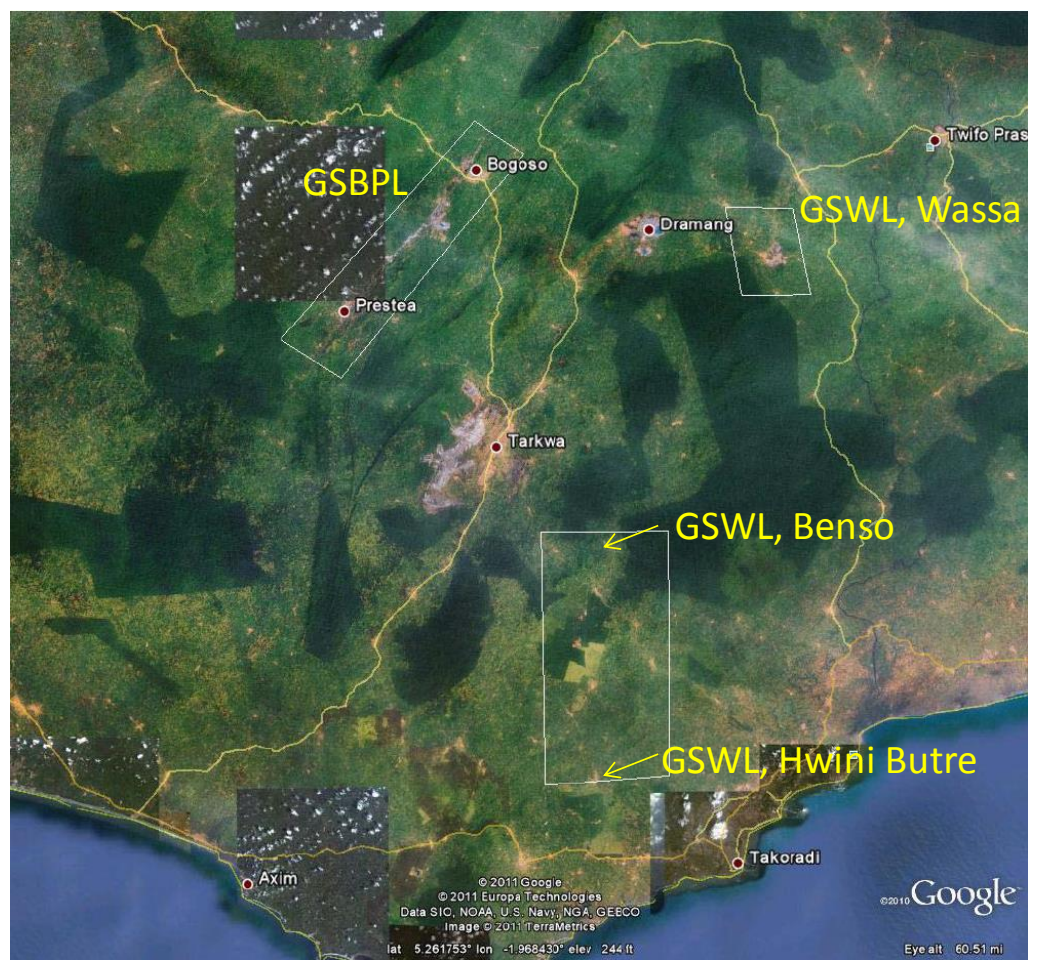

\section{Figure 2 Location of the GSR operations within Ghana}

\section{History of the Plant North operations}

\subsection{Prestea mining concession}

The Prestea concession has a long history of gold mining from at least the 18th Century, with large-scale mining dating back to the end of the 19th Century. Mining and processing has been undertaken at three main locations within the Prestea concession: Brumasi, Prestea Central and Bondaye (Knight Piésold, 2000), with underground mining being carried out from the 1870s until 2002.

Nationalised into a single identity in 1965, and subsequently privatised in the mid-1990s, the Prestea concession was originally awarded to Prestea Gold Resources (PGR), a company formed by the Prestea workforce opposed to the underground mine closure, in 2000. In 2001, following lengthy negotiations, the Prestea concession was split such that PGR retained underground rights and Bogoso Gold Limited (BGL) (renamed by GSR in August 2006 to GSBPL) obtained the surface rights.

Continued and unsustainable losses due to depressed gold prices and financial difficulties forced a cessation of underground activities in early 2002. This closure led to the loss of some 1,750 jobs, high unemployment and a large increase in unauthorised small-scale mining (Scott Wilson, 2003). In March 2002, GSBPL reached an agreement with PGR to form a joint venture, to be managed by GSBPL, for the assessment and future operations of the Prestea underground mine. Mining activities at Prestea continued with the Prestea Gold Resources, Prestea Sankofa Gold Ltd. and GSBPL operations, in addition to extensive areas of unauthorised ('galamsey') mining.

In June 2012, GSBPL initiated permitting for the recommencement of the Prestea underground mine. The recommencement of the underground is expected to require some 285 jobs to support the existing GSBPL operations. 


\subsection{Historic liability indemnity}

Given the 100 years of mining activity, BGL's 2001 agreement for the acquisition of the Prestea surface concession provides indemnity from the government of Ghana for the environmental liabilities emanating from these historic activities occuring before the purchase.

An extensive study in late 2001 resulted in the development of a detailed register of environmental liabilities within the Prestea concession, covering both historic liabilities (Knight Piésold, 2002) and a due diligence review of existing operations in the area, with a view to expected future liabilities (Knight Piésold, 2001).

These registers, supported by project baseline studies and impact assessments, provide evidence of the highly degraded nature of the Prestea area. Historic sulphide ore mining and roasting, small-scale galamsey operations, and unmanaged urban sources, have led to an array of pollution sources and resulting contamination. Whilst not the subject of this paper, the existing baseline conditions place additional burden on the company. As the most financially viable authorised business in the area, GSBPL is the target for any number of claims relating to effects not associated with its operations.

Regardless of the environmental indemnity, GSBPL has with its Plant North and present day projects, continued to examine opportunities to rectify historic liabilities in conjunction with our operations.

\subsection{Plant North project description}

In late 2002, BGL submitted an Environmental Impact Statement (EIS) for the Plant North operations (Scott Wilson, 2003) to the Ghanaian Environmental Protection Agency (EPA). The planned Plant North operations were to prevent the otherwise then imminent closure of the BGL operations, which at that time was expected to stop mining by the end of 2002.

Key aspects of the Plant North project included:

- Creation of the Plant North Pit - comprising two sections, the North Shaft and Main Plant.

- Construction of a temporary ore stockpile adjacent to the North Shaft section of the Plant North pit.

- Backfilling of voids, resulting from tailings retreatment operations in the Asuo Kofi Valley, using waste rock.

- Construction of a waste rock stockpile in the northern end of Asuo Kofi Valley to store waste from the Plant North pit during mining operations before backfilling could be undertaken.

- Ore haulage along the existing haul road from the west of the Ankobra Cemetery to the BGL Process Plant.

- Extension of the existing haul route to an intersection with the main Prestea-Bogoso public road, with the installation of a manned crossing, and then continuation of the haul route to the Ankobra River.

- Crossing of the Ankobra River using the existing road bridge and the construction of a haul road south of the bridge and along the route of a former public road to the Plant North Pit for use in the initial stages of the project and as a contingency route in the future.

- Conversion of the rail bridge across the Ankobra River for use by on-road dump trucks, together with the necessary connecting haul roads, as the principal haulage option.

- Construction of a haul route from the rail bridge to the proposed ore stockpile along the line of the existing, though currently disused, railway line right of way.

- Relocation of community buildings that were close to the Plant North pit, including a fuel station, Police Station, Post Office, and labour office, as well as access routes to this area. 
- Construction of a heavy equipment maintenance workshop to the north of the pit.

A total reserve of $5.1 \mathrm{Mt}$ was identified for the Plant North Pit comprising $1.35 \mathrm{Mt}, 0.95 \mathrm{Mt}$ and $2.8 \mathrm{Mt}$ of oxide, transition and primary ore, respectively (Table 1), and some $23 \mathrm{Mt}$ of waste rock.

Table 1 Summary of the Plant North Pit ore reserves and waste rock

\begin{tabular}{lcccccccc}
\hline $\begin{array}{l}\text { Plant North } \\
\text { Pit }\end{array}$ & \multicolumn{4}{c}{ Ore (kt) } & \multicolumn{4}{c}{ Waste (kt) } \\
& Oxide & Transition & Primary & Total & Oxide & Transition & Primary & Total \\
\hline North Shaft & 2,734 & 443 & 870 & 4,047 & 2,200 & 2,356 & 2,712 & 7,268 \\
Main Plant & 1,078 & 514 & 1,926 & 3,518 & 4,428 & 4,053 & 7,345 & 15,826 \\
Total & 1,351 & 956 & 2,796 & 5,103 & 6,628 & 6,409 & 10,057 & 23,094 \\
\hline
\end{tabular}

Estimated at a gold price of US\$300

The EIS identified a number of key project environmental and social impacts (Table 2). Whilst the operational technical aspects were reasonably well identified and assessed, it is in the arena of social and closure impact assessment that the assessments did not adequately identify risks or opportunities arising from the project.

\section{Table 2 Key project environmental and social impacts}

\begin{tabular}{|c|c|}
\hline Aspect/Impact & Description \\
\hline Acid rock drainage & Potentially acid generating, historical calcine tailings materials. \\
\hline Hydrology & $\begin{array}{l}\text { Four tributaries of the Ankobra River pass through the Prestea area. The Plant } \\
\text { North pit was located in the Asuo Kofi river valley. }\end{array}$ \\
\hline \multirow[t]{2}{*}{ Hydrogeology } & $\begin{array}{l}\text { Natural groundwater spring (Railway spring) encompassed by project waste } \\
\text { rock dump. }\end{array}$ \\
\hline & Pit water discharges to Asuo Kofi and Ankobra River. \\
\hline $\begin{array}{l}\text { Relocation/ } \\
\text { resettlement }\end{array}$ & $\begin{array}{l}\text { Solomon's Village, two access roads, power line, PSG tailings pipeline, Prestea } \\
\text { Post Office, Police Station, Labour office and Shell filling station affected by } \\
\text { project. }\end{array}$ \\
\hline Historic liabilities & $\begin{array}{l}\text { Beneficial remediation and clean up of the environmental degradation at Plant } \\
\text { North posing health and safety risks (Knight Piésold, 2002). }\end{array}$ \\
\hline Waste rock & $\begin{array}{l}\text { Progressive backfilling to reduce greenfield land use for temporary waste rock } \\
\text { storage. }\end{array}$ \\
\hline Noise and vibration & Prestea township 350 m from Plant North pit. \\
\hline Cultural & Asuo Kofi, principal deity of the area - shrine. \\
\hline Socio-economics & $\begin{array}{l}\text { Benefits accuring from the continuation of BGL's operations and adverse effects } \\
\text { of land take, haul traffic and possible migration to the area. }\end{array}$ \\
\hline
\end{tabular}

\section{$2.4 \quad$ Pre-project consultations}

The Plant North project EIS documents an extensive list of pre-project consultations carried out with traditional leaders, opinion leaders, and the statutory authorities (Table 3). 


\section{Table 3 Summary of consultation with affected stakeholders for the development of the Plant North pit}

\begin{tabular}{|c|c|}
\hline Stakeholder and Affected Groups & Issues \\
\hline $\begin{array}{l}\text { Community/opinion leaders, } \\
\text { stakeholder and affected groups, } \\
\text { social structural organisations }\end{array}$ & $\begin{array}{l}\text { Long-term mining plans for Prestea Concession and the Plant North } \\
\text { Project Meetings and consultations held regularly - participation } \\
\text { and obtain support through transparency and communication. }\end{array}$ \\
\hline Planning authorities & $\begin{array}{l}\text { Relocation of buildings close to the project footprint and rerouting } \\
\text { of access roads in the town. }\end{array}$ \\
\hline Banking institutions & Rerouting of access roads in the vicinity of the bank building. \\
\hline Education service & Relocation of two staff bungalows. \\
\hline Highways authority & Ore haulage route. \\
\hline Unions & Employment. \\
\hline Labour, police and postal services & Relocation of their buildings. \\
\hline Railways authority & $\begin{array}{l}\text { Use of railway foundation and Ankobra River rail bridge for ore } \\
\text { haulage. }\end{array}$ \\
\hline Telecommunications providers & Improvement of communication systems in Prestea. \\
\hline Water company & Water supply in Prestea/Himan and baseline conditions. \\
\hline \multirow[t]{2}{*}{ Minerals Commission } & Interface between surface and underground concessions. \\
\hline & $\begin{array}{l}\text { Proposed upgrading of water and sanitation reticulation in Prestea, } \\
\text { a project coordinated by the Minerals Commission. }\end{array}$ \\
\hline Mines Department & Interface between surface and underground concessions. \\
\hline \multirow[t]{2}{*}{ Minister of Mines } & Indemnity from the historical environmental liabilities. \\
\hline & $\begin{array}{l}\text { BGL assistance in the clean-up of the environmental liabilities on } \\
\text { behalf of the Government of Ghana. }\end{array}$ \\
\hline Other businesses & $\begin{array}{l}\text { Maintaining harmonious working relationships. } \\
\text { Specific impacts of operations on their endeavours. }\end{array}$ \\
\hline Schools & Financing the construction of additional classrooms/relocation. \\
\hline Solomon's Village & $\begin{array}{l}\text { Relocation of residential properties an outstanding commitment } \\
\text { from PSG Agreement reached on relocation, which is to take place } \\
\text { before September } 2002 \text {. }\end{array}$ \\
\hline State Gold Mining Corporation & Long-term use/demolition of their buildings. \\
\hline Power authority & Relocation of $161 \mathrm{kV}$ power lines and impacts of blasting. \\
\hline Water authority & Possible diversion of the Asuo Kofi Stream. \\
\hline
\end{tabular}

The evidence provided in the EIS would suggest consultations were representative and robust, spanning a wide variety of stakeholders and affected parties, however this case study prompts further scrutiny of the degree of shared understanding. Were consultations effective; was the information provided adequate; and was the critical importance of the synergy between commitments at project planning and what a proponent delivers to the community well understood? 


\section{$3 \quad$ Plant North operations}

\subsection{Permitting}

In November 2002, the EPA approved and issued permits for the operation, which not only extended the BGL life of mine but bridged a period in which other new ore sourced were identified and permitted. Key permit conditions included:

- Replacement of water supplies that may be affected by the development.

- Payment of compensation for land used and structures.

- Backfilling of the open pit.

- Management of blasting and blast effects.

- Security and safety at locations where the haulage route interacts with public roads.

- Monitoring and reporting for the effects identified in the EIS.

Whilst permitted by the EPA, the Plant North project was opposed by the community of Prestea from the outset. A 2005 incident investigation cited that the Chiefs and people of Prestea were unsupportive of the idea of open pit mining in Prestea, considering it imposed upon them by the EPA. A key community concern is the still held, widespread, belief that open pit operations would jeopardise the re-opening of the underground mine. The wealth and job creation resulting from the underground mining in Prestea is an aspect that has, with time, grown to almost legendary status within the local community. The Prestea underground mine has produced approximately nine million ounces of gold, the second highest production of any mine in Ghana, and in 2002, the underground mines in the Prestea area reportedly employed 1,800 people. There remains a strongly-held belief amongst the community of Prestea that an underground mine workforce would return to such a level.

In addition to the concerns over the effect on the underground feasibility, the approval of large scale, open pit mining was, and remains, in direct conflict with the livelihoods of unauthorised small scale mining (locally called galamsey), in which a sizable proportion of the Prestea population is currently engaged. Whilst unauthorised in Ghana, galamsey is a large employer that provides for many an instant income source and receives the financial backing of both foreign investors and, in many cases, local Traditional leaders. In a country of strongly held traditional land ownership, galamsey often receives the tacit support of the Chiefs, and other traditional leaders. At the time of the 2003 EIS (Scott Wilson, 2003), mining (both legal and unauthorised) was reported as the main source of employment in the Prestea area.

\subsection{Performance and relationships}

Ore was extracted from the Plant North pit from 2002 to 2006. Operations were considered to be relatively smooth from early 2003 until the fourth quarter of 2004, when the community became increasingly opposed to the mining operations culminating in a series of demonstrations over a six month period. An air-blast of $130 \mathrm{~dB}$ was seen as the trigger, and was aggravated by: reported effects on electrical items and dwellings; the announcement by the Government of Ghana to evict unauthorised small scale miners from BGL's Concessions; and the demolition of the Senior Staff Club House that was owned by BGL at the time.

Under increasing pressure from the community, the regulatory authorities became involved, identified a number of project attributes not in conformance with the EIS, and responded with a stop work order and new operating conditions. The section following provides a timeline that clearly illustrates a number of root causes, contributing factors and the resulting effects on the company and its relationships with the community and the stakeholders in general. 


\subsubsection{A smooth start interrupted by changing mine plans}

In November 2002, mining commenced with normal operating conditions. In early 2003, metallurgical problems resulted in the second phase mining operations being brought forward (non-refractory mining). In mid-2003, the mine plan was further changed to allow surface waste rock dumping of material originally scheduled as backfill. No objections were raised by the EPA to the modified mine plan and, despite the initial concerns of stakeholders, mining activities were performed at Plant North relatively smoothly from early 2003 until the last quarter of 2004.

\subsubsection{Triggering incident}

On 15 and 16 November 2004, blasting resulted in air blast overpressures of 134 and $130 \mathrm{~dB}$-L, respectively, as well as fly-rock reaching Neil Stevenson's Park about $150 \mathrm{~m}$ away. The Mines Department investigated without EPA involvement and found that a change in blasting supplier and new explosives product were the primary root causes. The community immediately reacted to the incident with claims of structural and equipment damage.

\subsubsection{Relationships strained}

A further blasting incident on 5 April 2005, with an air blast overpressure of $136 \mathrm{~dB}-\mathrm{L}$, and another in May 2005, where a shot was fired late under cloudy conditions (BGL did not have permission to delay blasting overnight) increased community concern. These blasting incidents and complaints from the Prestea Hospital relating to waste dumping in close proximity to their operations and over the Railway spring water source, led to an investigation by the EPA. The Mines Inspectorate directed waste rock storage in the area to cease, to which the EPA concurred.

The Regional Minister applied pressure to the Company to 'buy peace' in the community. BGL responded by making goodwill payments to community members claiming alleged damage to electrical items. The payments led to a further 860 claims from people located as far as $1,050 \mathrm{~m}$ from the pit. Additionally, the Odikro (Chief) was alleged to have taken money from people who received goodwill payments, contributing to the pressure for BGL to make further payments. BGL recognises the strategy as unsuccessful.

In mid May, the first compensation payments were made for the November 2004 blast incident. However, the subsequent blasts with high air overpressures catalysed the formation of the Concerned Citizens of Prestea. A petition was circulated within the community and on 15 June 2005, a major demonstration was held in the community demanding the cessation of surface mining in Prestea.

BGL responded to the event with the formation of a committee, including the Prestea Urban Council, Himan Chiefs (Traditional leaders), District Assembly and BGL, to attempt to resolve the outstanding issues. Claims of health effects had surfaced and ranged from claims that people had fallen out of bed during the blasts of concern, through to more general unspecified claims of dust exposure. By 29 July 2005, the committee submitted a report to the Omanhene (Paramount Chief), which concluded that whilst claims of health effects were not related to the project, there was an urgent need for further education of the Prestea community on the Plant North EIS. BGL admitted to having recognised this need, and whilst a road show had been planned for several months, it had not been finalised.

In the next two months, a number of international non-government organisations (NGOs) became involved in the issues and on 24 August 2005, the Wassa Association of Communities Affected by Mining (WACAM) and some other NGOs collaborated with the Concerned Citizens of Prestea to organise a demonstration and press conference. Throughout this period, BGL attempted to communicate with the community to seek resolution on several issues. However, the involvement of international NGOs, Parliamentary visits and repeated press/media involvement increased the difficulty for BGL to counter the unsubstantiated claims of health effects from the open pit mining operations.

On 3 September 2005, a press conference was held by the Concerned Citizens of Prestea. At the conference, the Member of Parliament (MP) was attacked as being insensitive to the plight of the citizenry given his perceived instrumental role in the surface mining rights being granted to BGL. Under increasing 
pressure and considerable media attention, the MP publically condemning BGL's pit operations. A flurry of inspections resulted and, following the identification by the EPA of some unmet EIS conditions, the EPA Executive Director advised BGL that operations would be stopped if key conditions and commitments of the EIS were not met. On 13 September 2005, BGL received a written stop work notice from the EPA in regards its Phase 3 operations.

Throughout late September 2005, media attention and protests continued. An adverse film broadcast was made of the operations on national television and on the evening of 27 September the EPA ordered a cessation of all mining activities from the following day. BGL was advised by the EPA that all issues surrounding the Police Station relocation, fence erection, by-pass road sealing and additional blasting procedures must be addressed before recommencement would be allowed.

In October 2005, an announcement by the Regional Security Council and a subsequent press release by the Minister for Mines advised that following the establishment by the Minerals Commission of alternative approved small scale mining areas (that could host up to 6,000 small scale miners), that illegal miners were to be evicted from the BGL concession. Whilst the media release referred to prior stakeholder consultations on the subject by the Minister and the Western Region Coordinating Council throughout early 2005, the unauthorised small scale miners branded the act as an initiative of BGL. Those sponsoring the unauthorised small scale mining activities, certain influencial political people, were widely believed to have initiated a campaign to encourage further protests against BGL. This event caused a quandary for BGL, who recognised the sensitivity of the issues surrounding the unauthorised galamsey, which provide critical primary and secondary incomes to a substantial number of people (especially women and children), and a genuine concern about the loss of income amongst the Prestea-Bondaye communities.

\subsubsection{A slow turning of the tide}

BGL started a determined campaign of communication on the project with a wide range of stakeholders. As consultations progressed, BGL noted a slow shift towards working with the company and not against; with a mutually shared view of increasing development to the township of Prestea.

In a landmark milestone act, the Himan chiefs signed a letter providing open support to BGL, distancing themselves from the negative press coverage and urging the EPA to allow mining to recommence. Under the guidance of the company's community affairs specialists, a Memorandum of Understanding (MOU) was reached between the Prestea Urban Council, the Himan Chiefs and the Prestea Senior Secondary Technical School for the first phase of an ambitious two floor, 12 classroom school block.

Following the implementation of corrective actions to address the EPA concerns, subsequent assessments by the EPA, and a series of consultations with stakeholders, the EPA lifted the operations ban on 31 October 2005.

The Plant North pit was operated under a new, heavily-prescriptive set of operating conditions from that time until the end of 2006, when depletion of the economically viable reserves resulted in project cessation.

\subsection{Post operational activities}

In December 2005, following consultations and negotiations, BGL entered into a Reclamation Security Agreement with the EPA. Established under the Environmental Assessment Regulations (LI 1652), the Reclamation Security Agreement details bank guarantee and cash securities to be established for the Concessions, reclamation rates and reclamation criteria, including landscape and land use completion criteria.

In November 2006, GSR applied to the EPA for a delay in backfilling of the Plant North pit whilst the potential of accessing underground mining targets from the pit was investigated. The EPA indicated that an application would be considered based on a full report of the feasibility of such a mine plan. Unclear on the way forward, GSR again corresponded with the EPA in December 2006. In November 2007, GSBPL was still 
conducting exploration drilling in the Plant North pit area and underground evaluations continued to site the portal in the Plant North pit.

The documentation of a rehabilitation and closure plan commenced in 2007, with a number of consultations with the stakeholder community and the EPA. Key stakeholders, including the Prestea Urban Council were engaged specifically in regards to the next land use and next uses for project infrastructure including haul roads, workshops and buildings.

Following the consultations, GSR finalised a Closure and Decommissioning Plan for the Plant North Complex in mid 2008 that was approved by the EPA in late 2008. The plan documents various next land uses for the project area including a mix of forest, agro forestry and farmland, as well as areas set aside for a bus station and other community infrastructure. Project haul roads were to be retained for future mining projects and community use, with buildings allocated for use as a community library, Agricultural Extension Office and other District uses.

By July 2008, backfilling had started. The monthly accounts from July 2008 to February 2010 show that progress was slow with just $0.59 \mathrm{Mm}^{3}$ of material movement over a 20 month period. Following continuing complaints by the Prestea community and the perception of a lack of action by GSBPL with regards the backfilling, the EPA placed a permitting moratorium on GSBPL in September 2009. Meanwhile, the backfilling work on the Plant North pit continued. In June 2010, GSR restated its commitment to the Plant North backfilling to the EPA. This further commitment and other evidence led to the EPA lifting the permitting moratorium in December 2010. GSBPL had increased the effort on the backfilling that resulted in the movement of some $12 \mathrm{Mm}^{3}$ of waste material by five local companies over about a two year period (Figure 3).

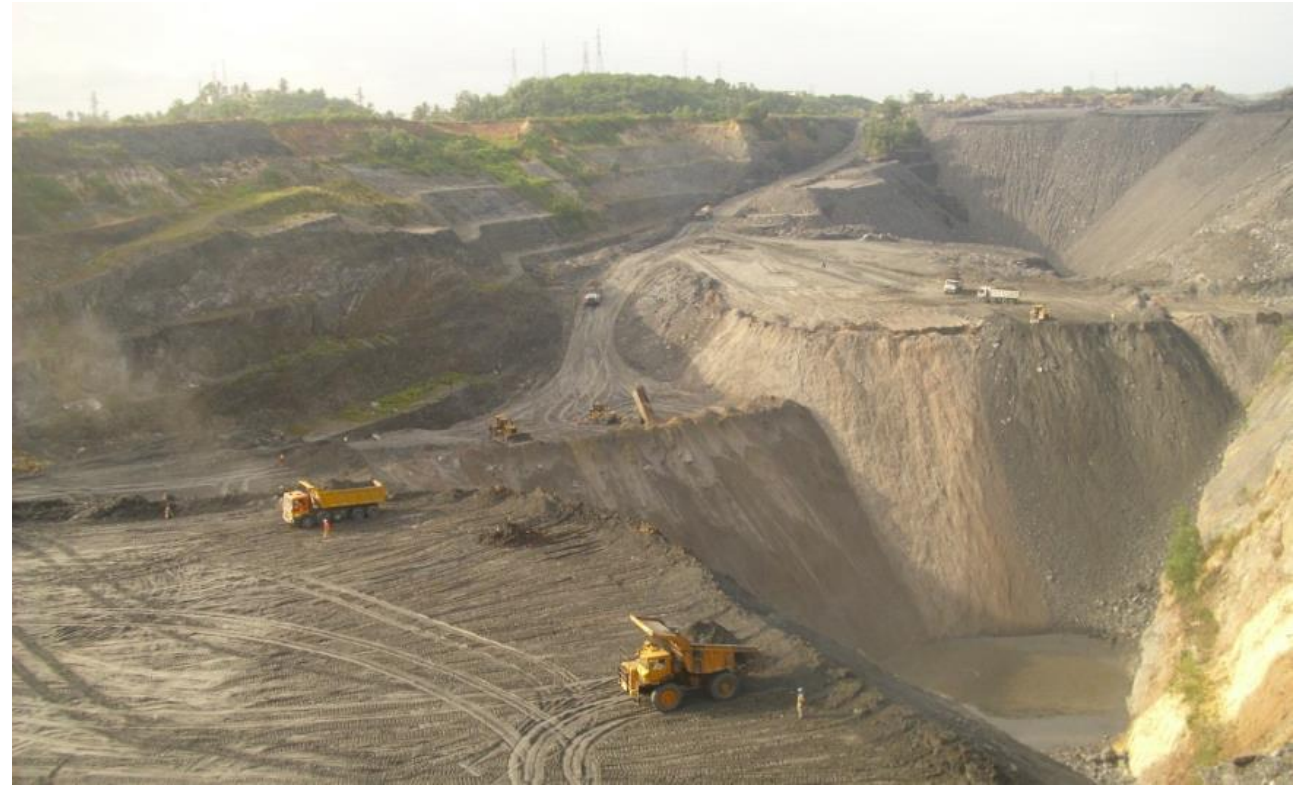

\section{Figure 3 Backfilling activities at the Plant North pit}

In August 2011, GSBPL was able to report to the EPA that it had substantially completed the Plant North pit backfilling (Figures 4 and 5). By the end of the first quarter in 2012, the entire area had been capped with compacted lateritic material. Field and laboratory testing was completed in early 2012 to confirm material properties and suitability of the site for vegetation. All of the tests met the required standards for compaction.

Following the placement of an additional oxide growth medium layer, the establishment of vegetation at the backfilled pit is ongoing. This program employs local labour, so providing employment opportunities for the Prestea community as part of GSBPL's commitment to local economic development. 


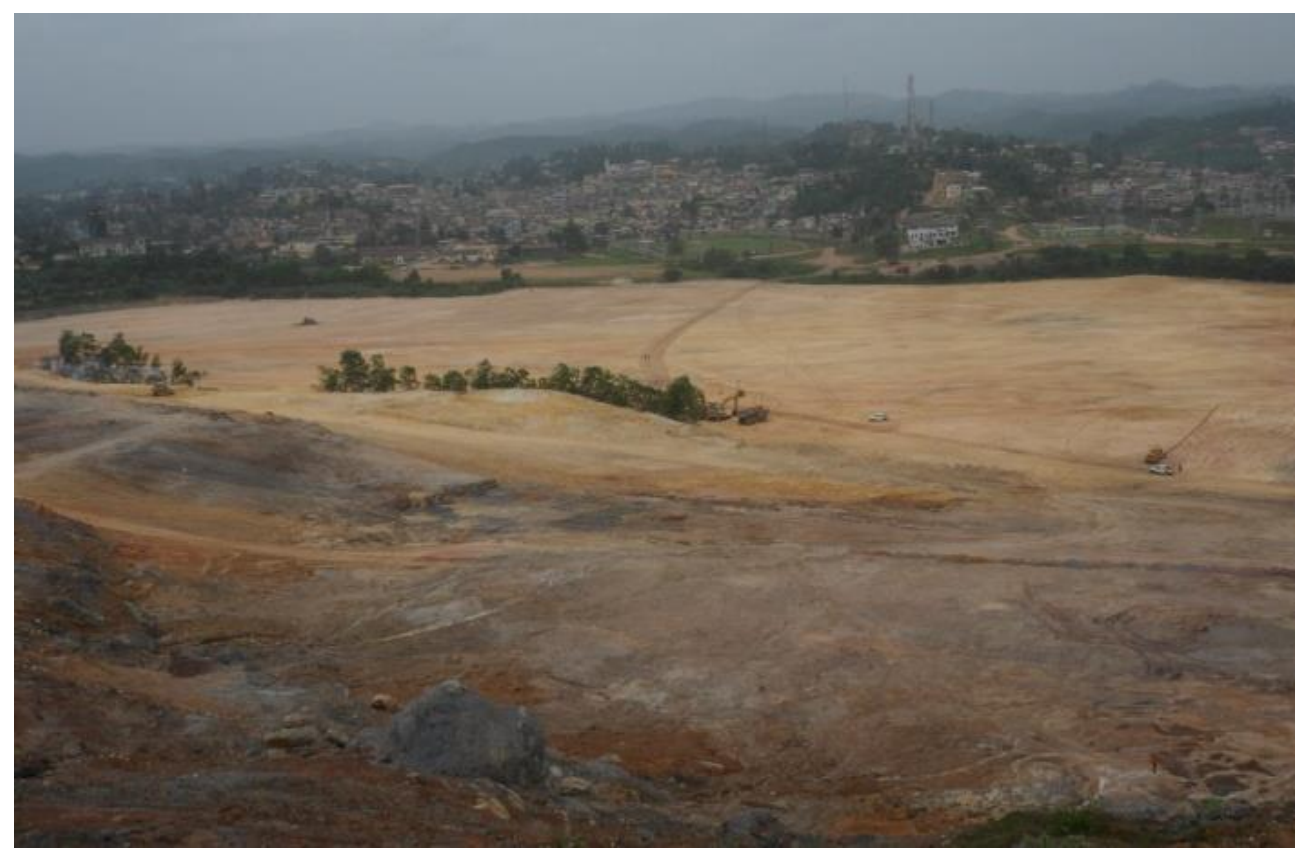

\section{Figure 4 Completed Plant North pit, looking toward Prestea}

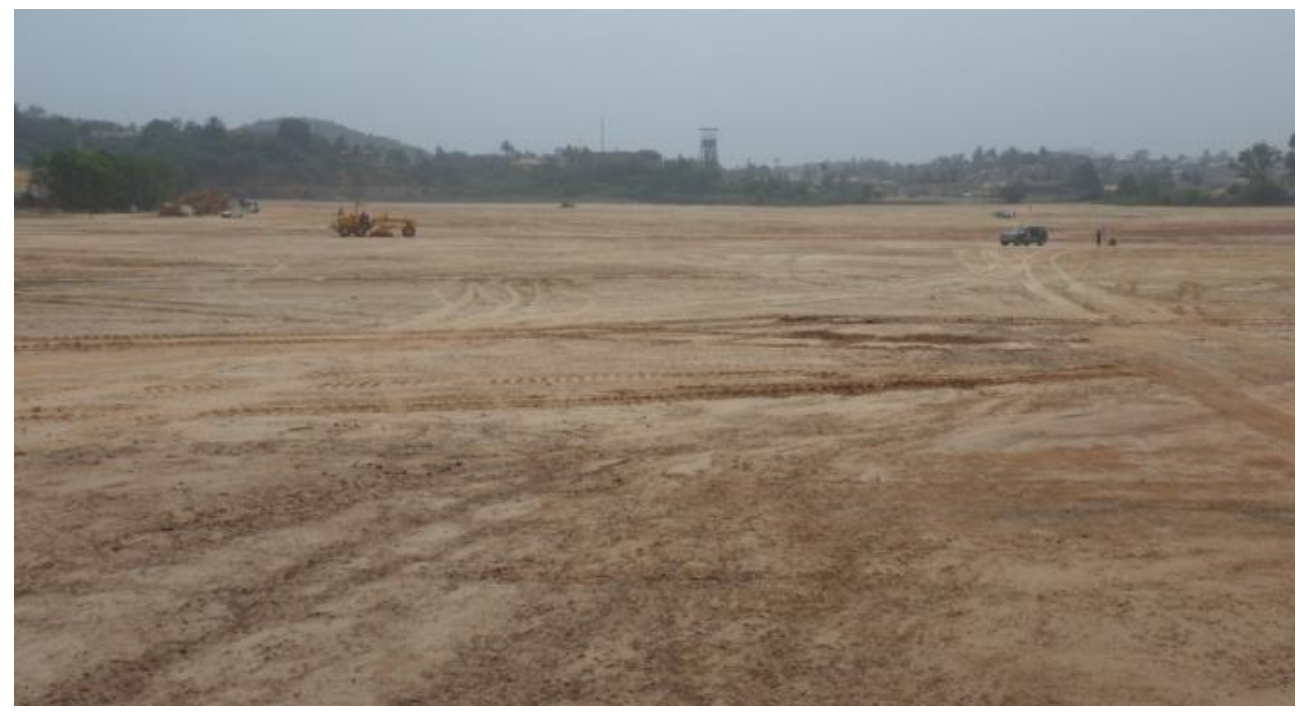

\section{Figure 5 Completed Plant North pit}

\subsection{Closure planning and commitments}

The earliest documented closure planning for the project was a Costed Reclamation Plan incorporated in the 2002 EIS. Reported as costing just US\$960,661, a key assumption in the plan was that costs excluded backfilling which was considered an operational expenditure, reflecting the then expected progressive backfilling of the pit (Table 4). The plan focussed mainly on the physical aspects of closure but did however propose land uses for each project area. It was noted that these had yet to be agreed with local communities and authorities.

In 2005, an updated valuation projected the backfilling alone to cost some US\$10.6M. By this time more detail had been resolved around next uses, both in respect of land areas and also infrastructure.

During the 2007 targetted consultations on next land use and post-closure infrastructure use, it was evident that the social aspects of closure were of increasing interest to stakeholders. Stakeholders were interested in maximising the potential benefits of the closure through infrastructure reuse and opportunities for sustainable livelihoods projects, as well as understanding the effects of the closure in 
regard to land availability, a premium commodity in Prestea. The documented Closure and Decommissioning Plan consequently provided greater detail on engineering and the next land use, although the closure costing had not evolved in unison.

To reflect the annual estimate of rehabilitation liability submitted to the EPA in 2011, GSBPL was required to post a bond for the project valued at US\$12M and as at April 2012, GSBPL has actually spent some US\$29M to date on the project.

\section{Table 4 Evolution of closure costing for Plant North}

\begin{tabular}{|c|c|c|c|}
\hline Year & Document & Costing (US) & Assumptions \\
\hline 2002 & EIS & $\$ 0.96 \mathrm{M}$ & $\begin{array}{l}\text { Costs exclude backfilling as this was considered } \\
\text { an operational cost. }\end{array}$ \\
\hline 2005 & Internal & $\$ 10.6 \mathrm{M}$ & $\begin{array}{l}\text { Assumed North Shaft pit section backfilled } \\
\text { during operations. }\end{array}$ \\
\hline 2007 & Internal & $\$ 4.8 \mathrm{M}$ & Backfill volume not documented. \\
\hline 2008 & Internal & $\$ 7.3 \mathrm{M}$ & Backfill volume determined as $3.8 \mathrm{Mm}^{3}$. \\
\hline 2010 & Internal & Not noted & Backfill volume determined as $8.1 \mathrm{Mm}^{3}$. \\
\hline 2011 & Bond & $\$ 12.0 \mathrm{M}$ & $\begin{array}{l}\text { Bond placed with Government of Ghana - bond } \\
\text { returned on completion of backfilling. }\end{array}$ \\
\hline 2012 & Internal & $\$ 29 M$ & April 2012 project to date actual expenditure. \\
\hline
\end{tabular}

Whilst the rehabilitation and closure plan for the Plant North Pit complex was accepted and approved by the EPA in 2008, the EPA has recently indicated that the final closure land use needs to be modified with further community consultation. GSBPL has received indications from the community that the area of the backfilled pit would be developed as part of an extension to the town (land in the area is limited). Therefore, GSBPL is currently working with the Prestea community to develop a closure plan for the overall Plant North complex that meets the mutual requirements of all parties. The finalisation of the next land use is yet to be completed but, as an interim measure, the surface of the backfilled and capped area is being stabilised using vegetation.

\section{$4 \quad$ Our lessons}

The consequences of inadequate consultation, communications gaps and the failure to understand heightened community concerns had reverberating impacts throughout GSR. The decisions made at Plant North not only affected the Plant North operations but also delayed the permitting of several subsequent projects.

The modification of mine plans without the integral understanding of the implications to closure planning led to a considerable increase in closure costs. Failure to adequately communicate the changing mine plans for an operation so close to a stakeholder community resulted in mistrust by the community of GSBPL. It continues to be a difficult task to regain the trust of the Prestea community and GSBPL continues to work on re-gaining that trust through open communication and positive actions. We are in the process of developing and signing specific community agreements for the GSBPL stakeholder communities that define development opportunities, local hiring and how relationships with GSBPL will be handled.

BGL/GSBPL have spent considerable time assessing the events surrounding the performance gaps, and have identified a number of lessons of value for our future operations:

- Consultation with communities must be clear and any ambiguities eliminated before the start of the project so that community expectations are appropriately managed. 
- The transition from project development teams to project operators must be seamless. Whilst those who negotiate permit conditions need to be very familiar with the project, it is those implementing the conditions that must be held accountable for compliance with the permit conditions and commitments.

- Project environmental impact assessments must fully address risks to all project phases, including closure, to ensure that the purpose and intent of commitments in regards to closure are well understood.

- Modifications in operational plans include an understanding of the other operational changes, especially for closure planning and implementation.

- Changes to the operation should consider stakeholder communities and their concerns, and need to be clearly outlined to the stakeholders as appropriate.

- Accuracy of pit void volume determinations needs to be improved to provide accurate estimates the backfilling costs.

- Closure planning is now required to a feasibility level before the rehabilitation planning is started.

- Rehabilitation planning implementation needs to include an evaluation of the abilities of contractors to perform the tasks assigned.

- Clarification of expectations of the regulatory authorities is to be incorporated in the closure planning, such that expectations are managed or the associated risks are understood and mitigated.

\section{$5 \quad$ Conclusions}

The mining industry often operates in challenging areas increasing the importance of the need to consult and include stakeholder communities in project plans and provide opportunities for local residents and businesses. At the start of this project, the first large scale open pit mine in the area, the belief that open pit mining would jeopardise underground mining (with its high employment) was of great concern to the stakeholders. This concern, combined with operating challenges and government initiatives to remove unauthorised small-scale miners, became a source of tension between the various stakeholders. More open communication and additional efforts to include local concerns could have reduced this relationship stress.

Closure planning proved to be challenging due to the changing conditions associated with the project. These conditions were both internal, through changing mine plans, and external, as a result of changing expectations, both on the part of the regulatory authorities and the stakeholder community.

In response to these changing conditions, GSR has established a review mechanism for closure planning and a corporate standard that defines the level of detail required for closure plans, relative to the status of the various operational elements. More details are required the closer the element is to closure. This allows better corporate financial planning and is reducing the risk of hidden costs associated with poor planning or less than optimal understanding of the tasks to be completed. Concurrent with the engineering, GSBPL's community team consult the local stakeholders and the regulatory authorities, with the objective of ensuring that the next land use is acceptable to all stakeholders. As GSBPL continues its work to concurrently rehabilitate and close operational units that are no longer required, a further evolution of the approach is expected. This will address the influence that changing socio-economic conditions continue to exert on the mining and processing operations.

\section{Acknowledgements}

Thank you to Mr Bill Archer and Mr Mike Hollywood for a number of the photographs provided in this paper. 


\section{References}

Knight Piésold (2000) Environmental Management Plan Report prepared for submission to Bogoso Gold Ltd for submission to Ghanaian EPA, November 2000.

Knight Piésold (2001) Bogoso Gold Limited, Environmental Due Diligence Audit, Prestea Sankofa Gold Ltd. Mining Operations, August 2001.

Knight Piésold (2002) Prestea Mining Lease, Register of Environmental Liabilities, May 2002.

Scott Wilson (2003) Bogoso Gold Limited, Prestea Mining Project, Plant North, Environmental Impact Statement, February 2003. 